IFN Working Paper No. 953, 2013

\title{
Market Specific News and Its Impact on Electricity Prices - Forward Premia
}

\author{
Ewa Lazarczyk
}




\title{
Market specific news and its impact on forward premia on electricity markets
}

\author{
Ewa Lazarczyk ${ }^{1}$
}

$17^{\text {th }}$ June, 2013

\section{Summary}

This paper studies the impact of market specific news on the short-time forward premia on the Scandinavian electricity market. I show that the short time premia between the day-ahead and intraday electricity prices on the Scandinavian market can be partly explained by the arrival of news specific to the power market. By exploring the types of news I show that production failures are most important in shaping the premia. Production disruptions in coal-powered units are most frequent and have the greatest effect on the differences between the day-ahead and intra-day prices.

Keywords: intra-day electricity market, forward premia, market specific news, supply shocks JEL Classification: D4, G14, L94, Q4.

\footnotetext{
${ }^{1}$ Research Institute of Industrial Economics (IFN). P.O. Box 55665, SE-102 15 Stockholm, Sweden, fax +468 665 4599,E-mail ewa.lazarczyk@ifn.se; Stockholm School of Economics, Department of Economics, Sveavägen 65, Stockholm, Sweden. E-mail ewa.lazarczyk@hhs.se
} 
I am grateful for helpful comments from Richard Friberg, Chloe le Coq, Harry-Paul Vander Elst, Endre Tvinnereim, seminar participants at Stockholm School of Economics and conference participants at BEEER 2013 in Bergen. Special thanks to Nils Carlson for his help with data and an introduction to Python. This research was financed within the IFN research program The Economics of Electricity Markets. 


\section{Introduction}

Electricity is an important commodity and input for many firms. Since it cannot be economically stored, in order to mitigate price volatility, firms engage in the trade of electricity contracts on future markets. Unexpectedly large spikes in electricity prices can be especially hurtful to industrial consumers and electricity retail companies. It is therefore important to understand the price adjustment process on markets of different horizons and the nature of shocks that influence these prices.

In this paper I study the impact of the market specific news on the price difference between the dayahead and the intra-day Scandinavian electricity market. I use hourly data covering the period from the $1^{\text {st }}$ of January 2006 to the $31^{\text {st }}$ December 2009. The information on the number and type of market specific news announced between January 2006 and December 2009 is obtained from the Urgent Market Messages dataset.

Several papers indicate that future prices are not unbiased predictors of future spot prices of electricity ${ }^{2}$. One explanation of this pattern is explored by Bessembinder and Lemmon (2002) henceforth BL. They model a market where identical electricity producers and electricity retailers, interested in maximizing their respective profit, participate in the future market so as to hedge their positions. BL show that in such an environment the difference between the future price and the expected spot price will negatively depend on the underlying spot price volatility and positively on the skewness of the price. These results indicate that the possibility of price spikes that arise from the convexity of the power production function and spot price variance are key elements in understanding the forward premium.

\footnotetext{
${ }^{2}$ Longstaff and Wang 2004, Douglas and Popova 2008, Hadsell and Shawky 2006, Karakatsani and Bunn 2005, Redl et al. (2009), Botterund et al. (2010).
} 
The theoretical foundations for thinking about forward premia on electricity markets have been proposed in the $\mathrm{BL}$ article. However, although explaining an important phenomenon about the relation of prices obtained for the same product at markets of different length, the $B L$ article does not explicitly incorporate the effect that new, last moment information has on the price discovery process.

I propose an explanation of premia that explicitly accounts for information that becomes known after the price on the future market is known but before the spot price has been established. This method enables me to predict the spot price deviation from the future price at time $t$ with the use of the distribution of the spot price until period $t-1$ and the last moment obtained information $I_{t}$.

Verifying the impact of public information on prices can be problematic since in practice it might be difficult to distinguish valid information that has impact on price from the noise. In the Nord Pool (the electricity market of the Nordic countries) market participants (MP) have an obligation to inform about special events impacting production, consumption and transmission through a channel called Urgent Market Messages (UMMs). The distribution of this news (UMMs) is skewed and negative information prevails. $55 \%$ of all messages are due to production or consumption failures, or problems on the transmission grid. A further $35 \%$ inform about planned maintenance, this is equivalent to a decrease in available capacity due to a shutdown of a plant. Although these messages are divided into different types more than $95 \%$ of these messages actually inform about capacity reductions implying that their distribution is skewed. The arrival of this news changes market participants' information set and this in turn may be responsible for the emergence of price differences between the intra-day and day-ahead markets.

I use this unique dataset to examine the effect information has on existence of price differences between the intra-day and day-ahead electricity markets. The intra-day electricity markets, although currently not that liquid, are growing as there is more intermittent power that due to its irregular 
nature is traded closer to the real time. The advantage of using the Urgent Market Messages data is that it provides a rich information structure in a clear-cut setup i.e. there is no noise in the data - all information is likely to be relevant for electricity prices as it reports on the electric power network events ${ }^{3}$.

I show that short time premia on Nord Pool exist which is consistent with results obtained from analysis of other markets ${ }^{4}$. Moreover I show that the arrival of market news in the time between the bidding for the day-ahead and intra-day markets has an important impact on the premia. A more detailed analysis of the messages reveals that fuel used by generators reporting news is also of importance. To the best of my knowledge this is the first study that explicitly takes into account problems on the grid and therefore provides a better understanding of changes in market fundamentals and of the consequences they have on prices.

This paper has seven sections. In the following section I describe the model of Bessembinder and Lemmon (2002) that proposed a theoretical foundation of the forward premia in the case of electricity markets. Next section provides a description of the Scandinavian electricity market. A description of the dataset can be found in section 4 . Section 5 presents the analysis of the premia and of the impact different news has on the prices. Section 6 discussed results and the last section concludes.

\section{Forward premium on electricity markets}

\footnotetext{
${ }^{3}$ For e.g. finance literature uses either pre-scheduled info or non-scheduled news; however in the latter case it might be difficult to judge which news are relative to the market performance

${ }^{4}$ Premia on electricity markets have been documented: Pennsylvania, New Jersey, Maryland (PJM) by Longstaff and Wang (2004) and Douglas and Popova (2008); the New York market (NYISO) by Hadsell and Shawky (2006); the British market by Karakatsani and Bunn (2005); the Scandinavian market has been analysed by Redl et al. (2009) and Botterund et al. (2010).
} 
A theoretical framework for studying forward premia in electricity market has been introduced by Bessembinder and Lemmon (2002) (BL henceforth) who show that in electricity markets the forward price will be a biased forecast of the spot price and explaining the premia through the moments of the spot price distribution.

They set up a general equilibrium model that assumes that the power companies are able to forecast the demand with high precision and participate in the spot market at known prices. The power generators are identical and risk-averse and the same applies to electricity consumers they are as well identical and risk-averse. These market participants trade on the spot market and use the future market to hedge their risk. Both parties use the future contracts as hedges to help maximize their objective profit functions. In the model the forward premium fluctuates in order to maintain the equilibrium between supply and demand for forward contracts. The electricity consumers, in order to avoid losses, react to increased spot price skewness and demand more forward contracts; this drives the forward price up (relative to the expected spot price) and increases the forward premium. On the other hand, increased variance of the spot price reduces retailers' net risk thus reducing their demand for forward contracts. The model leads to the following relationship:

Premium $_{t}=\beta_{0}+\beta_{1}$ Var $_{t}+\beta_{2}$ Skew $_{t}+\varepsilon_{\mathrm{t}}$

where variance and skeweness of the spot price explain the premium.

The theoretical model presented in this article has subsequently been tested on different electricity markets and different time horizons - Pennsylvania, New Jersey, Maryland (PJM) by Longstaff and Wang (2004) and Douglas and Popova (2008); the New York market (NYISO) by Hadsell and Shawky (2006); the British market by Karakatsani and Bunn (2005); the Scandinavian market has been analysed by Redl et al. (2009) and Botterund et al. (2010). 
The evidence from this literature confirms the theoretical results obtained by $B L$ and suggests that the daily pattern of the premia changes across markets. The BL model has been subsequently expanded through inclusion of variables that might impact the premia. Douglas and Popova (2008) argue that although electricity cannot be stored the underlying fuel often can, and estimate a refined model of forward premia where they include natural gas storage facilities. An explanation of forward premia through market fundamentals also appears in Karakatsani and Bunn's (2005) study. As the most influential factors of forward premia they identify: excess capacity on the previous day, spot volatility on the previous day and spread on previous and current day. Botterund et al. (2010) analyze hydro dominated power system and therefore they include reservoir levels and deviations in inflow while investigating the structure of future premia. However, not only supply side characteristics can determine premia for e.g. Ullrich (2010) expands the BL model by including excess capacity that is defined as the level of available supply in excess of contemporaneous demand. Other aspects that influence the premia could be risk measures. Longstaff and Wang (2004) in their analysis account for price, quantity and revenue uncertainty and show that premia reflect compensation for risk-taking

\section{The Scandinavian day-ahead and intra-day electricity markets}

The day-ahead market is the "main arena" for the electricity trading; based on bids and offers a unique price is determined that clears the market for each hour. The gate closure for the trades with delivery for the next day is at 12:00 CET, starting at 00:00 CET the contracts are delivered. The functioning of the intra-day market is somewhat different. The bidding into the Nordic intra-day market is continuous; it starts two hours after the day-ahead market closes and finishes one hour prior to delivery. The bids and offers are settled as soon as the offer meets demand and the range of

prices obtained for the same product (electricity traded at a particular hour) can vary from 
$769,6 € / \mathrm{MwH}$ to $0,1 € / \mathrm{MwH}$. It is important to notice that bidding into day-ahead and intra-day markets is not without costs. However the cost is small and only marginally larger for the intra-day market. The variable cost of placing a $1 \mathrm{MwH}$ bid in the day-ahead market is $0,035 €$ and $0,08 €$ in the intra-day market. The intra-day market is much smaller than the day-ahead. However it is growing as more intermittent power is brought on-line.

\section{Data}

\subsection{Price data}

In this analysis I use intra and day-ahead hourly prices for electricity traded on Nord Pool from $1^{\text {st }}$ of January 2006 until $31^{\text {st }}$ December 2009. These data are available upon request from the Nord Pool FTP server. I sort the data into 24 time series each representing a different hour. The intra-day prices correspond to hourly average prices for the entire market ${ }^{5}$ as they are not available at a more disaggregated level. In the following analysis I consider the series of the average intra-day prices for the whole market and the Swedish series of day-ahead prices ${ }^{6}$. Table1a reports chosen summary statistics for the intra-day and day-ahead electricity prices. All prices are quoted in Euros per megawatt hour (€/MWh). Hour 1 reports prices of electricity that was sold from 01:00 to 01:59 and Hour 23 from 23:00 to 23:59. As shown in the Table 1a, the average prices for electricity sold dayahead and intra-day vary throughout the day. In the early morning hours day-ahead prices are higher than the intra-day but this relationship is reversed during the rest of the day. It is interesting to note that the day-ahead maximum prices can reach very high levels while the intra-day prices do not seem to be as high. This however, is due to the fact that intra-day data used in this analysis are average data. The intra and day-ahead auctions' formats differ. The latter is a uniform auction while the

\footnotetext{
${ }^{5}$ Initially it covered only Sweden and then it grew to include other zones of the Nordic market. Therefore the Elbas series from January $1^{\text {st }} 2006$ to October $10^{\text {th }} 2006$ covers only Sweden and Finland and from 19.10.2006 31.12.2009 also Denmark and Kontek ${ }^{5}$ area.

${ }^{6}$ In the analyzed period 2006-2009 Sweden is one of the 13 zones in the Nord Pool. Sweden has been divided into four separate zones in autumn 2011. http://www.nordpoolspot.com/How-does-it-work/Bidding-

areas/Bidding-areas/
} 
former is a continuous discriminatory auction. Market participants do not encounter one average intra-day price while placing their bids but the range of prices. Table $1 \mathrm{~b}$ shows detailed information about intra-day prices. The High price indicates the highest price that the electricity was sold for, the Low price is the lowest price and the Range of prices is defined as the difference between the highest and the lowest price over the whole sample. In the minimum it corresponds to 0 , which indicates that there was just one trade on the intra-day market for the electricity delivered at the particular hour. The maximum difference between prices for the electricity delivered at the same hour reached over $700 €$ per MWh.

Table 1a.

Descriptive statistics of the intra-day and the day-ahead prices,

Nord Pool 2006 - 2009.

\begin{tabular}{lccrrccccr}
\hline \hline $\begin{array}{l}\text { Intra-day } \\
\text { price }\end{array}$ & Mean & $\begin{array}{l}\text { Std. } \\
\text { Dev. }\end{array}$ & Min & Max & $\begin{array}{c}\text { Day-ahead } \\
\text { price }\end{array}$ & Mean & $\begin{array}{l}\text { Std. } \\
\text { Dev. }\end{array}$ & Min & Max \\
\hline Hour 1 & 35,42 & 12,38 & 2,29 & 73,84 & Hour 1 & 36,78 & 12,83 & 1,88 & 78,34 \\
Hour 2 & 33,62 & 12,35 & 1,32 & 73,77 & Hour 2 & 35,20 & 13,00 & 0,06 & 78,15 \\
Hour 15 & 44,76 & 18,29 & 5,43 & 287,76 & Hour 15 & 43,25 & 17,06 & 4,82 & 379,3 \\
Hour 16 & 45,14 & 19,13 & 13,66 & 313,7 & Hour 16 & 44,13 & 38,39 & 5,45 & 1400 \\
Hour 17 & 48,28 & 23,12 & 14,15 & 398,27 & Hour 17 & 45,44 & 38,73 & 6,44 & 1400,1 \\
Hour 18 & 48,16 & 20,56 & 7,32 & 263,32 & Hour 18 & 44,37 & 14,71 & 7,07 & 200,01 \\
Hour 19 & 45,99 & 16,61 & 7,24 & 123,71 & Hour 19 & 43,67 & 14,52 & 6,69 & 145,01 \\
Hour 20 & 44,04 & 15,30 & 7,75 & 128,03 & Hour 20 & 42,68 & 13,99 & 7,01 & 100,26 \\
\hline \hline
\end{tabular}

Notes: This table presents summary statistics for the intra-day and day-ahead electricity prices on the Scandinavian electricity market Nord Pool during the period from $1^{\text {st }}$ of January 2006 to $31^{\text {st }}$ December 2009. Prices are reported in Euros per megawatt hour. The day-ahead price is the Swedish price.

\section{Table 1b.}

Summary statistics describing the intra-day prices, Nord Pool 2006 - 2009.

\begin{tabular}{llcccc}
\hline \hline Variable & Obs & Mean & Std.Dev. & Min & Max \\
\hline Range & 35064 & 10,82 & 16,49 & 0 & 769,6 \\
\hline
\end{tabular}




\begin{tabular}{llllll}
\hline High price & 35064 & 48,64 & 23,92 & 1,8 & 820 \\
Low price & 35064 & 37,82 & 15,13 & 0,1 & 250 \\
Average & 35064 & 42,82 & 18,06 & 1,23 & 398,27 \\
\hline \hline
\end{tabular}

Notes: The High price indicates the highest price that the electricity for a particular hour was sold for, the Low price is the lowest price and the Range of prices is defined as the difference between the highest and the lowest price over the whole sample. The dataset consists of hourly observations from Nord Pool (the Scandinavian electricity market) for the period from the $1^{\text {st }}$ of January 2006 to the $31^{\text {st }}$ of December 2009.

The data illustrates the right-skewed nature of electricity prices. The maximum day-ahead price reaches (for hour 17) 1400€ per MWh which is more than 30 times the mean value for this hour. Similar price behaviour (although on a smaller scale) is observed for the intra-day prices where the maximal average price is 8 times larger than its mean value.

Electricity is dispatched according to merit order - a ranking of energy sources according to their marginal costs - that gives the production function its "hockey-stick" shape. Flexible production with low start-up costs and the ability to adjust power generation quickly (most often based on gas, coal or oil) is responsible for setting the peak-time price. Inflexible production - nuclear and large thermal plants set the price in off-peak hours. Hydropower is a rather flexible source of generation; its low marginal cost makes it well suited to provide electricity on baseload terms. The Scandinavian power market is a hydro dominated system (around 60\%), followed by nuclear (22\%) and thermal generation. Wind generation is much smaller, delivering about $4 \%$ of the whole production at present but growing.

\subsection{Urgent Market Messages dataset}

According to market regulation all members of Nord Pool must disclose information concerning failures, plans and change of plans for maintenance or limitations affecting more than $100 \mathrm{MW}$ of generation or consumption and Transmission System Operators (TSOs) are obliged to report changes 
on transmission facilities. ${ }^{7}$ Events affecting generation, consumption or transmission are reported through Urgent Market Messages (UMMs) which are announced on an irregular basis.

The dataset that I use is composed of messages issued by Nord Pool participants and contains 22736 UMMs that were registered between $1^{\text {st }}$ of January 2006 and $31^{\text {st }}$ December 2009 . The dataset has a rich information structure. An individual message bears detailed information about the reported event for e.g. name of the company that is reporting news, type of news, affected capacity, time of the event start and an estimated end of the event. Each UMM has an individual registration time, which can be thought of as a point in time, but it also notifies about the start and estimated end of the event - a time interval. The estimated end of an event is often subject to change and a follow-up message would inform about it. In many cases the actual end of an event will be later that initially planned - the event will be prolonged - but sometimes it takes less time to restore the power system back to normal and the event ends earlier.

In this study I am only interested in messages that are registered after the day-ahead market has closed and before the bidding for the intra-day market has concluded and therefore I use only part of all available UMMs. From the whole set I choose news that was not available while submitting the bidding strategies into the day-ahead market but arrive in time to influence the decisions concerning the intra-day market. This leaves 14091 messages which content can possible influence the price formation on the intra-day market. Among these, 7752 correspond to failures, 4999 to maintenance plans, 1179 are "special information" and 161 inform about consumption or production changes. 12153 UMMs were issued by market participants (producers and consumers) and 1938 by the Transmission System Operators (TSOs). The arrival of messages is not distributed uniformly over the day. There are few messages in the early morning hours - between 24:00 and 5:59 - but their number grows over time with the peak around the time of the closure of the day-ahead market.

\footnotetext{
${ }^{7}$ Implementation of annex to regulation EC 1228/2003

http://www.nordpoolspot.com/Documents/Exchange\%20Information/EnclEIno78.pdf
} 
Figure 2.

UMMs announcements by time of the day

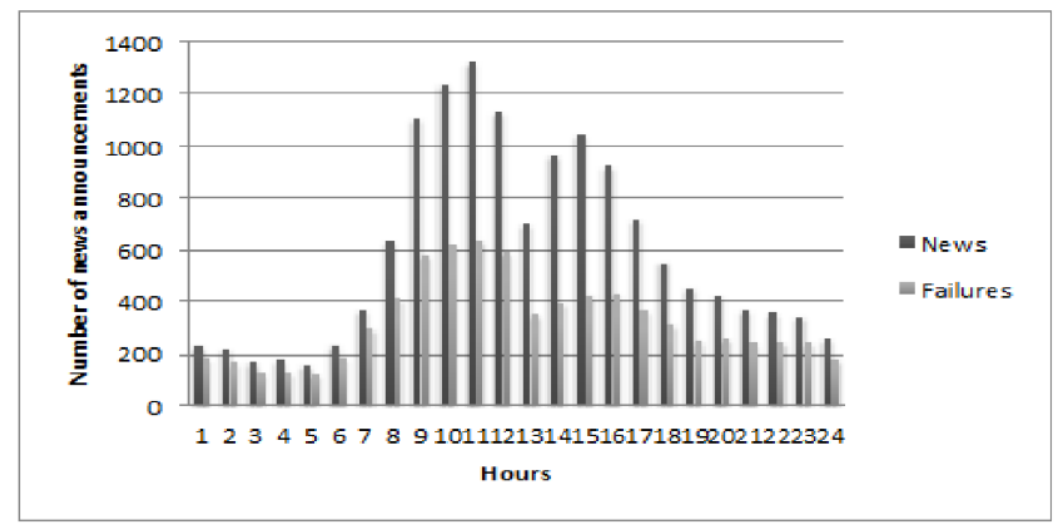

Notes: This graph shows total number of UMMs and UMMs informing about failures per hour.

Another important piece of information that I extract from the UMMs is the fuel type used by the market participant that reports the news. Failures of coal- based production units are most frequent - there are 2557 messages informing about a failure of a coal plant in my dataset. Another important source of failures in the time frame that I study is hydro-generation with 2429 UMMs and nuclear power plants with 824 messages. Moreover, as electricity is dispatched according to merit order, it is important to distinguish news informing about the marginal production from those about base-load generation. Therefore I group the UMMs into two categories: Marg and Base.

Overall using the UMMs dataset I create seven variables. The $U M M_{t}$ is the number of novel messages that arrived before time $t$ informing about a capacity change at time $t$. Failure $_{t}$ is the number of novel messages that arrived before time $t$ informing about a failure at time $t$. NuclearFailure $_{t}$ is the number of novel messages that arrived before time $t$ informing about a failure of nuclear production at time $t$. HydroFailure $t_{t}$ is the number of novel messages that arrived before time $t$ informing about a failure of hydro production at time . CoalFailure $_{t}$ is the number of novel messages that arrived before time $t$ informing about a failure of coal production at time $t$. 
$\operatorname{Marg}_{t}$ is the number of novel messages that arrived before time $t$ informing about problems reported by generation using coal, gas or oil. Base $_{t}$ is the number of novel messages that arrived before time $t$ informing about the problems reported by generation using nuclear or hydropower. All these variables consider only information that arrived after the day-ahead market has already closed and the intra-day market has been still open.

\section{Empirical strategy}

\subsubsection{Premia}

Empirical studies have proven that in electricity markets the forward premium, defined as the difference between the forward price and the ex-post spot price, may differ systematically from zero (Longstaff and Wang 2004, Douglas and Popova 2008, Hadsell and Shawky 2006, Karakatsani and Bunn 2005, Redl et al. (2009), Botterund et al. (2010)).

In this analysis I investigate the price relation between the day-ahead market and the intra-day market. On the intra-day market electricity can be traded up to one hour before the delivery, while at the day-ahead market prices for each of the hours of the coming day are known around 1 p.m. on the day before the delivery. Both markets trade the same product but at different moments in time. As I am interested in price formation on the short-term electricity markets, I define the premium as the difference between the day-ahead price and the intra-day price.

Premium $_{t}=$ "Day - ahead price" ${ }_{t}-$ "Intra - day price" ${ }_{t}=\beta+\varepsilon_{\mathrm{t}}$

\subsubsection{Impact of information on premium}


Information concerning the physical properties of the power grid (failures, maintenance, bottlenecks) plays a particular role. Physical characteristics on the grid can change quite rapidly having an impact on the available size of the supply and this is why it is important for market participants to have the most updated information. The risk of a reduction in available production is an uncertainty that market participants face. In order to judge on the relation of the price difference on these markets MP (market players) need to update their information set $\Omega_{t}$ which in moment $t$ includes price development $(p)$ up to moment $t-1$ and last moment information $I_{t}$ that reflects the most current information about market fundamental risk. These elements of the information set enable MP to take a decision about price t for electricity.

$\Omega_{t}=\left\{p(t-1), I_{t}\right\}$

The presence of premia is influenced by characteristics of the spot price ${ }^{8}$ but what seems even more important are events that occur in between the bidding for the two markets, in this case - after the day-ahead market has closed and before the closure of the intra-day market. Tomorrow's spot prices deviate from forward prices in the case of unexpected shocks that change the information set of bidders.

The distribution of news is skewed and one type of information dominates - capacity reductions. Other categories of news e.g. maintenance, special information appear more sporadically. The increases in capacity appear as information on problems on consumer side when because of a halt in consumer's production less electricity will be used. Other source of capacity increase is due to follow-up news that inform about an event on the grid that provoked an initial capacity reduction but has ended earlier than estimated and thus the production unit is on-line earlier. For the period between the actual end of the event up to the initially reported end there is an increase of capacity due to the power unit being back in operation.

\footnotetext{
${ }^{8}$ Bessembinder and Lemmon (2002);
} 
Not including this information into the equation as a separate variable but instead leaving it in the error term results in the disturbance term that is not normally distributed and moreover leads to a specification bias. Therefore in order to account for all the elements that are important for the presence of premium I include the information variable - UMM.

Premium $_{t}=\beta_{0}+\alpha_{1}$ UMM $_{t}+\beta_{1}$ Var $_{t-1}+\beta_{2}$ Skew $_{t-1}+\varepsilon_{1 \mathrm{t}}$

The $U M M_{t}$ is the information at time $t$ and $\operatorname{Var}_{t-1}$ and $S k e w_{t-1}$ are price developments up to the last known moment $t-1$. Since the news distribution is skewed and capacity reductions are most frequent source of messages the expected impact of the information on the premia is negative.

$\frac{\text { Premium }_{t}}{\partial U M M_{t}}<0$

Electricity is dispatched according to the merit order and the most expensive production is used only in times of high demand - peak hours while the base load production is constantly active. Due to this heterogeneity of production it is interesting to verify the impact of messages informing about problems with different types of production.

In peak hours most of available production is already in use therefore the information about grid fundamentals should have the biggest effect in the peak hours. Prices are already high and a reduction in available capacity would mean that the missing production needs to be replaced by even more expensive production.

\subsection{Analysis}

I start the analysis by investigating the distribution of premia over 24 hours. I estimate equation 4 separately for each hour. The coefficient on constant $\beta$ informs about the size of premium (Table 2, Column (1)).

Premium $_{t}="$ Day - ahead price" ${ }_{t}-$ "Intra - day price" ${ }_{t}=\beta+\varepsilon_{\mathrm{t}}$ 
The day-ahead price is the Swedish price and the intra-day price is an average of the prices obtained for electricity for a particular hour. It covers all trades for the particular product ${ }^{9}$. It does not include any time constraints for when the trade took place as long as the traded product was the same. Further on I evaluate the impact of the last moment market specific information (UMM) on the premium (equation 5). The impact of information about failures is estimated in equation 6.

Premium $_{t}=\beta_{0}+\alpha_{2}$ UMM $_{t}+\beta_{1}$ Var $_{t-1}+\beta_{2}$ Skew $_{t-1}+\beta_{3} X+\varepsilon_{1 \mathrm{t}}$

Premium $_{t}=\beta_{0}+\alpha_{2}$ Failure $_{t}+\beta_{1}$ Var $_{t-1}+\beta_{2}$ Skew $_{t-1}+\beta_{3} X+\varepsilon_{2 \mathrm{t}}$

It is not only the appearance of the information per se but also the content of the information that has effect on premia. It is important which market fundamentals are changed. Among those that are expected to influence the premia are the ones impacting generation mix - fuels ${ }^{10}$. Therefore equation (8) distinguishes the events from equation (5) into those that affect marginal production (Marg) or base-load production (Base). The equation (7) again examines failures but tests separately for the impact of the three fuels that report failures most often - coal, nuclear and hydro.

Premium $_{t}=\beta_{0}+\alpha_{5}$ Coal Failure $_{t}+\alpha_{6}$ Nuclear Failure $_{t}+\alpha_{7}$ Hydro Failure $_{t}+\beta_{1}$ Var $_{t-1}+$ $\beta_{2}$ Skew $_{t-1}+\beta_{3} X+\varepsilon_{4 \mathrm{t}}$

Premium $_{t}=\beta_{0}+\alpha_{3}$ Marg $_{t}+\alpha_{4}$ Base $_{t}+\beta_{1}$ Var $_{t-1}+\beta_{2}$ Skew $_{t-1}+\beta_{3} X+\varepsilon_{3 \mathrm{t}}$

All equations take into account the effect variance and skewness of the underlying spot price has on premia. In order to take into account weekly seasonality I include a vector of dummies - $X$ representing the days of the week (from Monday to Saturday). The variables UMM, Failure, Marg, Base, Coal Failure, Nuclear Failure and Hydro Failure measure the number of messages that arrive

\footnotetext{
${ }^{9}$ The intra-day market functions as a continuous discriminatory auction as opposed to the day-ahead market that is an uniform auction.

${ }^{10}$ Some studies have shown that fuel costs may not influence high frequency electricity prices (Guiguis and Felder 2004) one of the reasons being their slow evolution over the studied period (Karakatsani and Bunn 2008). In this study I do not attempt to use fuel prices per se, rather I am interested what effects sudden changes in production using a particular fuel have on premia.
} 
before time $t$ and inform about capacity changes due to different reason at time $t$. This information is novel and unscheduled therefore variables are exogenous.

As the market participants are assumed to derive information about the future distribution of electricity prices by observing the moments of the underlying spot (intra-day) price distribution up to the last available moment $t$-1, each specification includes rolling-window variance and skewness of the intra-day price calculated on the basis of the last 24 hours.

Each equation is tested separately for every hour giving in total 24 models for each specification. I estimate these models using OLS with Newey-West standard errors (HEC) to address correlation and heteroscedasticity of the error terms.

\section{Results}

\subsection{Premia}

Results indicate (table 2, Column (2)) that premia between the intra-day and day-ahead prices exist and that their sign vary throughout the day. Apart from hour 16 and 23, all premia are statistically different from zero. Figure 3, which plots constant values from equation (3) for each of the 24 regressions, shows the premia and displays a clear pattern of positive premia in the off-peak hours and negative in the peak hours. Negative premia prevail, indicating that for most of the time the intra-day price is higher than the day-ahead one, making it more expensive for market participants to balance their position by buying the electricity closer to the real time. At its peak, hour 11 , it is $4,6 €$ higher than the price of electricity sold with the day-ahead contract which represents a 9,2\% 
(negative) premium. Positive premia occur in the early morning hours with the peak around 3 o'clock $-5,43 \%{ }^{11}$ premium.

\section{Figure 3.}

\section{Average premium over a day}

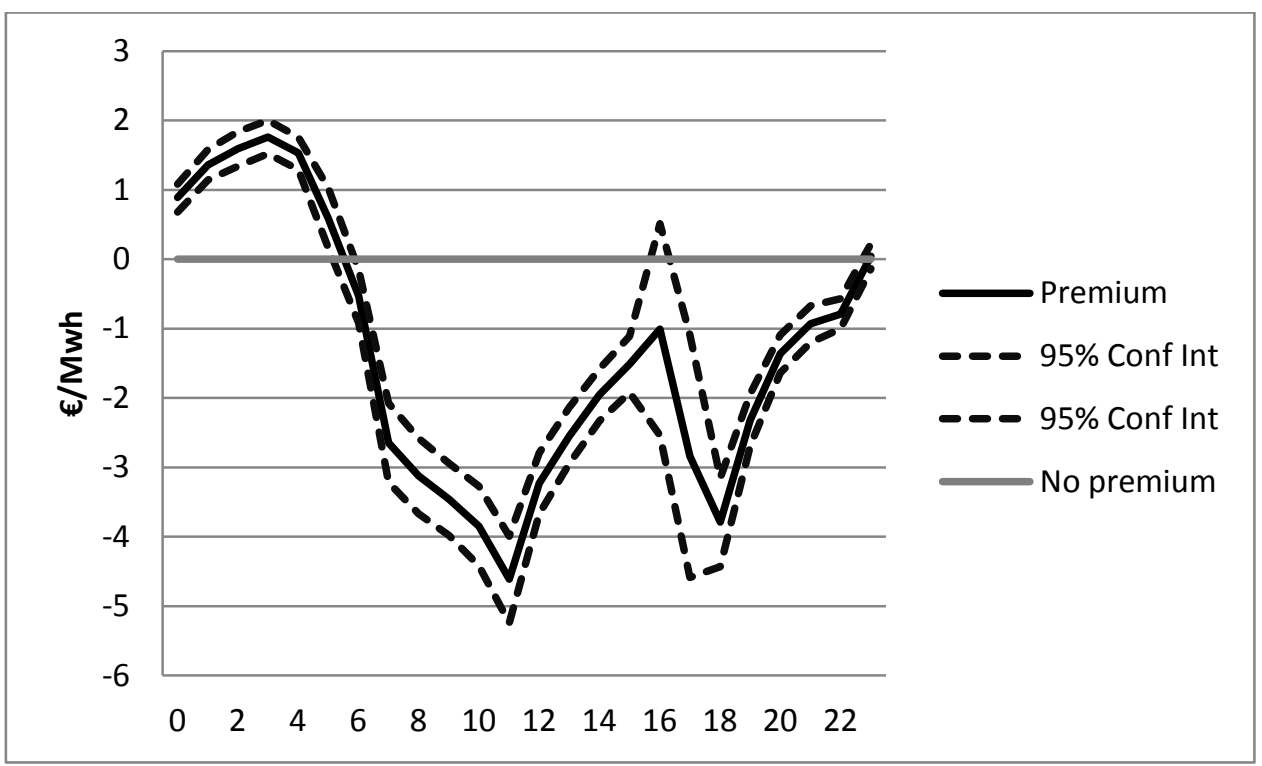

Notes: This figure shows evolution of an average forward premium (calculated as a difference between the day-ahead and the intra-day price at the Nord Pool 2006-2009) over 24 hours as opposed to a no premium scenario indicated with the horizontal line.

\subsection{Impact of information about failures on premia}

Urgent Market Messages have an impact on premia mostly in the peak hours (table 2, column (2)). The biggest impact is identified in the morning when the arrival of messages decreases premium by $1,1 €$ which constitutes almost $30 \%$ of the mean premium observed for that hour (hour 10 with 3,847 negative premium). As the UMM dataset contains different news categories I divide the UMMs according to different fuel types. Further on I distinguish the outages news from the other type of

\footnotetext{
${ }^{11}$ Compared with the intra-day mean price for the hour.
} 
news and report the results for the three most frequent failures. Messages informing about changes to production or consumption affecting marginal type of units are significant for 14 out of 24 hours (table 2, col. (3)) and news informing about changes to base-load for 10 out of 24 hours (table 2, col. (4)). The negative effect of marginal production is observed mainly during peak-hours while the baseload production has a negative impact on premia even in off-peak hours. The effect of marginal production's news reaches the highest level at hour 17, (table 2, col.(3)) which constitutes $87 \%$ of the mean premium observed for this time of the day (hour 17 with 2,844 negative premium table 2 , col.(1)).

As it can be expected failures have a negative effect on premia. Breakdowns on the production site or transmission grid lead to less available electricity and thus prices on the intra-day market rise (table 3). Failure coefficients are significant for 17 out of 24 hours, a new information about failure raises the intra-day price with the increase ranging from $0,2 €$ to $1,3 €$, having an overall negative effect on the premium.

\subsection{Information about failure of particular generation type and its impact on premia}

During the period that I analyse, the hydro-based generation has registered breakdowns for the longest time-periods. Outages observed by the hydro production amounted to 17797 hours in total. Coal plants failures were reported to last 14712 hours in total and the nuclear generation's failures covered 4040 hours.

Breakdowns of units based on coal have the largest effect on the premia - coal failure coefficients are significant for 16 out of 24 hours. The price difference caused by this type of breakdown can reach up to 2,6€ per MWh which constitutes $92 \%$ of the mean premium observed for this hour (hour 17 with 2,844 negative premium (table2, col.1)). The coal-based production is often used during peak hours when the demand is high and therefore prices are subsequently high too. A malfunction during this time period leads to a scarcity of marginal production. In order to sustain the supply and demand 
balance other units, possibly more expensive, have to start their production (or increase their production which due to ramping costs is more expensive).

In all specifications I observe weekly seasonality with working days having a significant negative Ushape effect on premia in the peak-hours.

As a part of sensitivity analysis I run the same regressions as in equations 5 through 8 but using dummy variables for "news" and "no news" hours instead of the total number of messages per hour. The obtained results (tables 4 and 5 ) are similar to the original ones with the absolute effects slightly larger in the dummy variable specifications.

\section{Conclusions}

This paper studies the impact of market specific news on the short-time forward premia on the Scandinavian electricity market - Nord Pool. The contribution of the paper is three-fold. First, I indicate that the last moment market specific messages are important for the explanation of the premium on the electricity market. I show that the short time forward premia are in general negative with a clear pattern emerging during the day - positive premia during off-peak hours and negative premia during peak-hours. I associate the emergence of this pattern with the arrival of news that becomes known in the time-slot between the biddings for the two markets. The distribution of news is skewed and one type of information - capacity reductions - prevails which lowers the premium. The UMM dataset is perfectly suited for my analysis as it contains little noise data. All information announced by UMMs is relevant to the market making the dataset ideal to study the impact of news on price behaviour.

Secondly, using as an example the intra-day and the day-ahead electricity markets, I study the nature of short-time premia on the Nord Pool. Due to increased amounts of intermittent renewable power 
that is being brought on-line, intra-day electricity markets are expected to become more important over time and carry more trade as they give an opportunity to trade power closer to real time. Unlike the day-ahead market, future markets and the real-time (balancing) market that have gained much attention in the literature, the intra-day market has not been subject to a deeper analysis. Forward premia of different horizons have been studied in a variety of markets but the intra-day market has been largely left out of the analysis. Since this market is growing it is important to understand the price between this and the "main" day-ahead market.

The third contribution is to verify how messages, informing about sudden events affecting the power market, influence the premia. I show that information about the supply side shocks affecting different fuel types have a significant impact on the price differences between the two markets and should be taken into account while discussing short-term premia. During the analysed period failures to the coal-based generation had the biggest impact on the premia. Moreover skewness and variance of the underlying intra-day price, although statistically significant, have a small, almost negligible financial impact on the price differences between the two markets.

The paper shows that although the sign of the premia fluctuates over time in short time markets, it is mostly negative indicating that in peak hours the intra-day price is higher than the future price (dayahead price in this case). This finding is in opposition to the studies that describe premia of longer horizon where it is the future price that is higher than the spot price ${ }^{12}$. The high intra-day price can be seen as a reimbursement for sellers that keep extra capacity close to the real-time and therefore bear the risk of not selling in case there is no demand - thus it reflects the market fundamentals risk. The results indicate that information about the shocks to the power system should be included into the analysis of the premia as it explains a substantial part of the difference between the future and spot prices. On the Nord Pool day-ahead and intra-day markets market specific news are largely

\footnotetext{
${ }^{12}$ Redl et al 2009 finds positive premia for one month ahead premia; and Botterund et al. 2010 find positive premia for several weeks ahead; both studies describe Scandinavian electricity market.
} 
responsible for the occurrence of premia. They however cannot explain all price differences indicating that premia on this market do exist even after accounting for shocks.

\section{References:}

Bessembinder, H., Lemmon, M.L., (2002), Equilibrium pricing and optimal hedging in electricity forward markets, The Journal of Finance, Vol. LVII, No. 3, pp. $1347-1382$.

Borenstein, S., Bushnell. J., Knittel, Ch.,R., Wolfram, C., (2008), Inefficiencies and market power in financial arbitrage: A study of California's electricity markets, The Journal of Industrial Economics, V. LVI, No. 2, pp. $347-378$.

Botterud, A., Kristiansen, T., Ilic, M.,D., (2010), The relationship between spot and futures prices in the Nord Pool electricity market, Energy Economics (32), pp. $967-978$.

Demirer, R., Kutan, A.M., (2010), The behaviour of the crude oil spot and future prices around OPEC and SPR announcements: An event study perspective, Energy Economics (32), pp. 1467 - 1476.

Douglas, S., Popova, J., (2008), Storage and the electricity forward premium, Energy Economics (30), pp. $1712-1727$.

Guirguis, H., Felder, F., (2004), Further advances in forecasting day-ahead electricity prices using time series models, KIEE International Transactions on Power Engineering, 4, pp. $159-166$.

Hadsell, L., Shawky, H.A., (2006), Electricity price volatility and the marginal cost of congestion: an empirical study of peak hours on the NYISO market, 2001 - 2004, The Energy Journal, 27, 2, pp. 157 179.

Kaldor, N., (1939), Speculation and economic stability, The Review of Economic Studies, 7, pp. 1 - 27.

Karakatsani, N.V., Bunn, D.W., (2005), Diurnal reversals of electricity forward premia, Working Paper, London Business School.

Karakatsani, N., Bunn, D. W., (2008), Forecasting electricity prices: the impact of fundamentals and time-varying coefficients, International Journal of Forecasting (24), pp. $764-785$.

Keynes, J.M., (1930), A Treatise on Money, Macmillan, London.

Longstaff, F. A., Wang, A. W., (2004), Electricity forward prices: a high-frequency empirical analysis, The Journal of Finance, Vol. LIX, No. 4, pp. $1877-1900$.

Lucia. J. and Schwartz E., (2002), Electricity prices and power derivatives: evidence from the Nordic power exchange, Review of Derivatives Research, 5, 1, pp. $5-50$.

Redl, Ch., Haas, R., Huber, C., Böhm, B., (2009), Price formation in electricity forward markets and the relevance of systematic forecast errors, Energy Economics (31), pp. $356-364$. 


\section{ANNEX:}

\section{Table 2.}

\section{Existence of Premia and Market Specific News and Their Impact on Premia}

This table presents results from regressions which details are provided below. Column (1) reports the evolution of the average difference between the day-ahead and the intra-day price the premium over a day. Column (2) reports coefficient $\alpha_{1}$ from the equation:

Premium $_{t}=\beta_{0}+\alpha_{1} U M M_{t}+\beta_{1}$ Var $_{t-1}+\beta_{2}$ Skew $_{t-1}+\beta_{3} X+\varepsilon_{1 t}$;

Columns (3) and (4) report coefficients $\alpha_{3}$ and $\alpha_{4}$ from equation:

Premium $_{t}=\beta_{0}+\alpha_{3}$ Marg $_{t}+\alpha_{4}$ Base $_{t}+\beta_{1}$ Var $_{t-1}+\beta_{2}$ Skew $_{t-1}+\beta_{3} X+\varepsilon_{3 \mathrm{t}}$

In all regressions OLS with Newey-West standard errors procedure is used separately for each hour. The R-squares for different equations are in range from 0,01 to 0,278 for results in col.(2) and from 0,01 to 0,28 for specification in columns 3 and 4 .

\begin{tabular}{|c|c|c|c|c|}
\hline Premia & Const. (1) & UMM(2) & Marginal (3) & Base (4) \\
\hline Premium h0 & $\begin{array}{c}0.891 \\
(0.105)^{* * *}\end{array}$ & $\begin{array}{l}-0.211 \\
(0.092)^{*}\end{array}$ & $\begin{array}{c}0.020 \\
(0.208)\end{array}$ & $\begin{array}{l}-0.360 \\
(0.131)^{* *}\end{array}$ \\
\hline Premium h1 & $\begin{array}{l}1.360 \\
(0.111)^{* * *}\end{array}$ & $\begin{array}{l}-0.107 \\
(0.090)\end{array}$ & $\begin{array}{c}0.067 \\
(0.194)\end{array}$ & $\begin{array}{l}-0.244 \\
(0.128)\end{array}$ \\
\hline Premium h2 & $\begin{array}{l}1.594 \\
(0.125)^{* * *}\end{array}$ & $\begin{array}{l}-0.094 \\
(0.109)\end{array}$ & $\begin{array}{c}0.225 \\
(0.248)\end{array}$ & $\begin{array}{l}-0.344 \\
(0.142)^{*}\end{array}$ \\
\hline Premium h3 & $\begin{array}{l}1.761 \\
(0.123)^{* * *}\end{array}$ & $\begin{array}{l}-0.029 \\
(0.094)\end{array}$ & $\begin{array}{c}0.107 \\
(0.178)\end{array}$ & $\begin{array}{l}-0.136 \\
(0.149)\end{array}$ \\
\hline Premium h4 & $\begin{array}{l}1.531 \\
(0.120)^{* * *}\end{array}$ & $\begin{array}{l}-0.076 \\
(0.094)\end{array}$ & $\begin{array}{c}0.075 \\
(0.168)\end{array}$ & $\begin{array}{l}-0.200 \\
(0.153)\end{array}$ \\
\hline Premium h5 & $\begin{array}{c}0.592 \\
(0.222)^{* *}\end{array}$ & $\begin{array}{c}0.276 \\
(0.186)\end{array}$ & $\begin{array}{c}0.475 \\
(0.246)\end{array}$ & $\begin{array}{l}-0.001 \\
(0.205)\end{array}$ \\
\hline Premium h6 & $\begin{array}{l}-0.530 \\
(0.196)^{* *}\end{array}$ & $\begin{array}{l}-0.073 \\
(0.205)\end{array}$ & $\begin{array}{c}0.046 \\
(0.252)\end{array}$ & $\begin{array}{l}-0.047 \\
(0.196)\end{array}$ \\
\hline Premium h7 & $\begin{array}{l}-2.653 \\
(0.289)^{* * *}\end{array}$ & $\begin{array}{l}-0.641 \\
(0.277)^{*}\end{array}$ & $\begin{array}{l}-1.317 \\
(0.396)^{* * *}\end{array}$ & $\begin{array}{l}-0.043 \\
(0.298)\end{array}$ \\
\hline Premium h8 & $\begin{array}{l}-3.122 \\
(0.275)^{* * *}\end{array}$ & $\begin{array}{l}-0.867 \\
(0.267)^{* *}\end{array}$ & $\begin{array}{l}-1.611 \\
(0.399)^{* * *}\end{array}$ & $\begin{array}{l}-0.264 \\
(0.303)\end{array}$ \\
\hline Premium h9 & $\begin{array}{l}-3.460 \\
(0.266)^{* * *}\end{array}$ & $\begin{array}{l}-1.014 \\
(0.245)^{* * *}\end{array}$ & $\begin{array}{l}-1.420 \\
(0.403)^{* * *}\end{array}$ & $\begin{array}{l}-0.778 \\
(0.298)^{* *}\end{array}$ \\
\hline Premium h10 & $\begin{array}{l}-3.847 \\
(0.293)^{* * *}\end{array}$ & $\begin{array}{l}-1.136 \\
(0.247)^{* * *}\end{array}$ & $\begin{array}{l}-1.312 \\
(0.379)^{* * *}\end{array}$ & $\begin{array}{l}-1.029 \\
(0.298)^{* * *}\end{array}$ \\
\hline Premium h11 & $\begin{array}{l}-4.612 \\
(0.318)^{* * *}\end{array}$ & $\begin{array}{l}-0.945 \\
(0.245)^{* * *}\end{array}$ & $\begin{array}{l}-1.047 \\
(0.388)^{* *}\end{array}$ & $\begin{array}{l}-0.876 \\
(0.311)^{* *}\end{array}$ \\
\hline Premium h12 & $\begin{array}{l}-3.230 \\
(0.224)^{* * *}\end{array}$ & $\begin{array}{l}-0.741 \\
(0.162)^{* * *}\end{array}$ & $\begin{array}{l}-0.763 \\
(0.238)^{* *}\end{array}$ & $\begin{array}{l}-0.752 \\
(0.230)^{* *}\end{array}$ \\
\hline Premium h13 & $\begin{array}{l}-2.545 \\
(0.207)^{* * *}\end{array}$ & $\begin{array}{l}-0.473 \\
(0.139) * * *\end{array}$ & $\begin{array}{l}-0.751 \\
(0.223) * * *\end{array}$ & $\begin{array}{l}-0.433 \\
(0.201)^{*}\end{array}$ \\
\hline Premium h14 & $\begin{array}{l}-1.952 \\
(0.190)^{* * *}\end{array}$ & $\begin{array}{l}-0.331 \\
(0.114)^{* *}\end{array}$ & $\begin{array}{l}-0.447 \\
(0.177)^{*}\end{array}$ & $\begin{array}{l}-0.268 \\
(0.163)\end{array}$ \\
\hline
\end{tabular}




\begin{tabular}{cllll}
\hline Premium h15 & -1.515 & -0.183 & -0.404 & -0.148 \\
& $(0.205)^{* * *}$ & $(0.157)$ & $(0.225)$ & $(0.179)$ \\
Premium h16 & -1.014 & -0.831 & -1.552 & -0.640 \\
& $(0.778)$ & $(0.659)$ & $(1.026)$ & $(0.560)$ \\
Premium h17 & -2.844 & -1.139 & -2.487 & -0.979 \\
& $(0.895)^{* *}$ & $(0.605)$ & $(1.164)^{*}$ & $(0.583)$ \\
Premium h18 & -3.791 & -0.560 & -0.762 & -0.428 \\
& $(0.325)^{* * *}$ & $(0.169)^{* * *}$ & $(0.293)^{* *}$ & $(0.248)$ \\
Premium h19 & -2.321 & -0.611 & -0.914 & -0.352 \\
& $(0.193)^{* * *}$ & $(0.111)^{* * *}$ & $(0.202)^{* * *}$ & $(0.150)^{*}$ \\
Premium h20 & -1.361 & -0.464 & -0.710 & -0.387 \\
& $(0.140)^{* * *}$ & $(0.070)^{* * *}$ & $(0.140)^{* * *}$ & $(0.115)^{* * *}$ \\
Premium h21 & -0.935 & -0.126 & -0.268 & -0.043 \\
& $(0.134)^{* * *}$ & $(0.079)$ & $(0.125)^{*}$ & $(0.102)$ \\
Premium h22 & -0.790 & -0.299 & -0.417 & -0.216 \\
& $(0.111)^{* * *}$ & $(0.054)^{* * *}$ & $(0.093)^{* * *}$ & $(0.091)^{*}$ \\
Premium h23 & 0.040 & -0.089 & -0.142 & -0.078 \\
& $(0.090)$ & $(0.047)$ & $(0.073)$ & $(0.074)$ \\
\hline \hline
\end{tabular}

$* p<0.05 ; * * p<0.01 ; * * * p<0.00$

\section{Table 3.}

\section{Impact of messages informing about failures on premia}

This table presents results from regressions which details are provided below.

Column (1) shows coefficient $\alpha_{2}$ from equation: Premium $_{t}=\beta_{0}+\alpha_{2}$ Failure $_{t}+\beta_{1}$ Var $_{t-1}+$ $\beta_{2}$ Skew $_{t-1}+\beta_{3} X+\varepsilon_{2 \mathrm{t}}$ Columns (2), (3) and (4) show coefficients $\alpha_{5}, \alpha_{6}$ and $\alpha_{7}$ from equation: $\quad$ Premium $_{t}=\beta_{0}+\alpha_{5}$ Coal Failure $_{t}+\alpha_{6}$ Nuclear Failure $_{t}+\alpha_{7}$ Hydro Failure $_{t}+$ $\beta_{1}$ Var $_{t-1}+\beta_{2}$ Skew $_{t-1}+\beta_{3} X+\varepsilon_{4 \mathrm{t}}$ In all regressions OLS with Newey-West standard errors procedure is used separately for each hour. The R-squares for different equations are in range from 0,01 to 0,027 for both specifications.

\begin{tabular}{lllll}
\hline Premia & Failure (1) & Failure coal (2) & Failure nuclear (3) & Failure hydro (4) \\
\hline Premium h0 & -0.269 & -0.000 & -0.830 & -0.233 \\
& $(0.108)^{*}$ & $(0.234)$ & $(0.323)^{*}$ & $(0.163)$ \\
Premium h1 & -0.209 & -0.106 & -0.665 & -0.235 \\
& $(0.104)^{*}$ & $(0.193)$ & $(0.381)$ & $(0.154)$ \\
Premium h2 & -0.190 & 0.090 & -0.877 & -0.265 \\
& $(0.139)$ & $(0.408)$ & $(0.389)^{*}$ & $(0.186)$ \\
Premium h3 & -0.090 & -0.175 & -1.193 & 0.057 \\
& $(0.111)$ & $(0.230)$ & $(0.362)^{* *}$ & $(0.180)$ \\
Premium h4 & -0.108 & -0.210 & -1.379 & 0.069 \\
& $(0.110)$ & $(0.205)$ & $(0.388)^{* * *}$ & $(0.168)$ \\
\hline
\end{tabular}




\begin{tabular}{|c|c|c|c|c|}
\hline Premium h5 & $\begin{array}{c}0.187 \\
(0.191)\end{array}$ & $\begin{array}{c}0.059 \\
(0.283)\end{array}$ & $\begin{array}{l}-0.608 \\
(0.416)\end{array}$ & $\begin{array}{c}0.120 \\
(0.208)\end{array}$ \\
\hline Premium h6 & $\begin{array}{l}-0.197 \\
(0.184)\end{array}$ & $\begin{array}{l}-0.521 \\
(0.262)^{*}\end{array}$ & $\begin{array}{l}-0.045 \\
(0.461)\end{array}$ & $\begin{array}{l}-0.127 \\
(0.197)\end{array}$ \\
\hline Premium h7 & $\begin{array}{l}-0.591 \\
(0.264)^{*}\end{array}$ & $\begin{array}{l}-1.445 \\
(0.434)^{* * *}\end{array}$ & $\begin{array}{c}0.634 \\
(0.609)\end{array}$ & $\begin{array}{l}-0.194 \\
(0.354)\end{array}$ \\
\hline Premium h8 & $\begin{array}{l}-0.792 \\
(0.247)^{* *}\end{array}$ & $\begin{array}{l}-1.535 \\
(0.476)^{* *}\end{array}$ & $\begin{array}{l}-1.073 \\
(0.737)\end{array}$ & $\begin{array}{l}-0.349 \\
(0.353)\end{array}$ \\
\hline Premium h9 & $\begin{array}{l}-1.065 \\
(0.224)^{* * *}\end{array}$ & $\begin{array}{l}-1.328 \\
(0.492)^{* *}\end{array}$ & $\begin{array}{l}-0.566 \\
(0.710)\end{array}$ & $\begin{array}{l}-1.173 \\
(0.441)^{* *}\end{array}$ \\
\hline Premium h10 & $\begin{array}{l}-1.133 \\
(0.221)^{* * *}\end{array}$ & $\begin{array}{l}-1.401 \\
(0.464)^{* *}\end{array}$ & $\begin{array}{l}-1.089 \\
(0.754)\end{array}$ & $\begin{array}{l}-1.281 \\
(0.381)^{* * *}\end{array}$ \\
\hline Premium h11 & $\begin{array}{l}-0.831 \\
(0.246)^{* * *}\end{array}$ & $\begin{array}{l}-1.084 \\
(0.470)^{*}\end{array}$ & $\begin{array}{l}-0.112 \\
(0.737)\end{array}$ & $\begin{array}{l}-0.948 \\
(0.415)^{*}\end{array}$ \\
\hline Premium h12 & $\begin{array}{l}-0.837 \\
(0.191)^{* * *}\end{array}$ & $\begin{array}{l}-0.910 \\
(0.320)^{* *}\end{array}$ & $\begin{array}{l}-0.091 \\
(0.493)\end{array}$ & $\begin{array}{l}-1.017 \\
(0.303)^{* * *}\end{array}$ \\
\hline Premium h13 & $\begin{array}{l}-0.607 \\
(0.170)^{* * *}\end{array}$ & $\begin{array}{l}-1.141 \\
(0.310)^{* * *}\end{array}$ & $\begin{array}{l}-0.264 \\
(0.460)\end{array}$ & $\begin{array}{l}-0.451 \\
(0.290)\end{array}$ \\
\hline Premium h14 & $\begin{array}{l}-0.383 \\
(0.142)^{* *}\end{array}$ & $\begin{array}{l}-0.528 \\
(0.252)^{*}\end{array}$ & $\begin{array}{l}-0.815 \\
(0.405)^{*}\end{array}$ & $\begin{array}{l}-0.211 \\
(0.233)\end{array}$ \\
\hline Premium h15 & $\begin{array}{l}-0.254 \\
(0.146)\end{array}$ & $\begin{array}{l}-0.465 \\
(0.281)\end{array}$ & $\begin{array}{l}-0.822 \\
(0.502)\end{array}$ & $\begin{array}{c}0.044 \\
(0.200)\end{array}$ \\
\hline Premium h16 & $\begin{array}{l}-0.722 \\
(0.568)\end{array}$ & $\begin{array}{l}-1.244 \\
(0.950)\end{array}$ & $\begin{array}{l}-1.015 \\
(0.889)\end{array}$ & $\begin{array}{l}-0.051 \\
(0.589)\end{array}$ \\
\hline Premium h17 & $\begin{array}{l}-1.308 \\
(0.626)^{*}\end{array}$ & $\begin{array}{l}-2.622 \\
(1.266)^{*}\end{array}$ & $\begin{array}{c}0.022 \\
(1.178)\end{array}$ & $\begin{array}{l}-0.684 \\
(0.704)\end{array}$ \\
\hline Premium h18 & $\begin{array}{l}-0.688 \\
(0.202)^{* * *}\end{array}$ & $\begin{array}{l}-0.973 \\
(0.456)^{*}\end{array}$ & $\begin{array}{c}0.410 \\
(0.500)\end{array}$ & $\begin{array}{l}-0.777 \\
(0.332)^{*}\end{array}$ \\
\hline Premium h19 & $\begin{array}{l}-0.582 \\
(0.131)^{* * *}\end{array}$ & $\begin{array}{l}-0.968 \\
(0.285)^{* * *}\end{array}$ & $\begin{array}{c}0.207 \\
(0.351)\end{array}$ & $\begin{array}{l}-0.473 \\
(0.211)^{*}\end{array}$ \\
\hline Premium h20 & $\begin{array}{l}-0.538 \\
(0.097)^{* * *}\end{array}$ & $\begin{array}{l}-1.042 \\
(0.217)^{* * *}\end{array}$ & $\begin{array}{l}-0.161 \\
(0.255)\end{array}$ & $\begin{array}{l}-0.389 \\
(0.162)^{*}\end{array}$ \\
\hline Premium h21 & $\begin{array}{l}-0.194 \\
(0.093)^{*}\end{array}$ & $\begin{array}{l}-0.424 \\
(0.170) *\end{array}$ & $\begin{array}{l}-0.163 \\
(0.248)\end{array}$ & $\begin{array}{l}-0.080 \\
(0.135)\end{array}$ \\
\hline Premium h22 & $\begin{array}{l}-0.343 \\
(0.077)^{* * *}\end{array}$ & $\begin{array}{l}-0.699 \\
(0.168)^{* * *}\end{array}$ & $\begin{array}{l}-0.553 \\
(0.228)^{*}\end{array}$ & $\begin{array}{l}-0.166 \\
(0.116)\end{array}$ \\
\hline Premium h23 & $\begin{array}{c}-0.132 \\
(0.061)^{*}\end{array}$ & $\begin{array}{c}-0.250 \\
(0.104)^{*}\end{array}$ & $\begin{array}{c}-0.433 \\
(0.198)^{*}\end{array}$ & $\begin{array}{r}-0.063 \\
(0.102) \\
\end{array}$ \\
\hline
\end{tabular}




\section{Table 4.}

\section{Existence of Premia and Market Specific News and Their Impact on Premia}

This table presents results from regressions which details are provided below.

Column (1) reports the evolution of the average difference between the day-ahead and the intraday price - the premium over a day. Column (2) reports coefficient $\alpha_{1}$ from the equation:

Premium $_{t}=\beta_{0}+\alpha_{1}$ UMM $_{t}+\beta_{1}$ Var $_{t-1}+\beta_{2}$ Skew $_{t-1}+\beta_{3} X+\varepsilon_{1 t}$;

Columns (3) and (4) report coefficients $\alpha_{3}$ and $\alpha_{4}$ from equation:

Premium $_{t}=\beta_{0}+\alpha_{3}$ Marg $_{t}+\alpha_{4}$ Base $_{t}+\beta_{1}$ Var $_{t-1}+\beta_{2}$ Skew $_{t-1}+\beta_{3} X+\varepsilon_{3 \mathrm{t}}$

In all regressions OLS with Newey-West standard errors procedure is used separately for each hour. Variables UMM, Marginal and Base are zero-ones variables with 0 when there is no news informing about particular type of failure in the hour and 1 in the opposite case.

\begin{tabular}{|c|c|c|c|c|}
\hline Premia & Const.(1) & UMM(2) & Marginal(3) & Base (4) \\
\hline Premium h0 & $\begin{array}{l}0.891 \\
(0.105)^{* * *}\end{array}$ & $\begin{array}{l}-0.702 \\
(0.219)^{* *}\end{array}$ & $\begin{array}{l}-0.108 \\
(0.232)\end{array}$ & $\begin{array}{l}-0.574 \\
(0.211)^{* *}\end{array}$ \\
\hline Premium h1 & $\begin{array}{l}1.360 \\
(0.111)^{* * *}\end{array}$ & $\begin{array}{l}-0.719 \\
(0.234)^{* *}\end{array}$ & $\begin{array}{l}-0.134 \\
(0.233)\end{array}$ & $\begin{array}{l}-0.546 \\
(0.221)^{*}\end{array}$ \\
\hline Premium h2 & $\begin{array}{c}1.594 \\
(0.125)^{* * *}\end{array}$ & $\begin{array}{l}-0.692 \\
(0.262)^{* *}\end{array}$ & $\begin{array}{c}0.153 \\
(0.281)\end{array}$ & $\begin{array}{l}-0.729 \\
(0.245)^{* *}\end{array}$ \\
\hline Premium h3 & $\begin{array}{l}1.761 \\
(0.123)^{* * *}\end{array}$ & $\begin{array}{l}-0.458 \\
(0.256)\end{array}$ & $\begin{array}{l}-0.049 \\
(0.264)\end{array}$ & $\begin{array}{l}-0.339 \\
(0.255)\end{array}$ \\
\hline Premium h4 & $\begin{array}{l}1.531 \\
(0.120)^{* * *}\end{array}$ & $\begin{array}{l}-0.507 \\
(0.250)^{*}\end{array}$ & $\begin{array}{l}-0.081 \\
(0.253)\end{array}$ & $\begin{array}{l}-0.534 \\
(0.242) *\end{array}$ \\
\hline Premium h5 & $\begin{array}{c}0.592 \\
(0.222)^{* *}\end{array}$ & $\begin{array}{c}0.444 \\
(0.668)\end{array}$ & $\begin{array}{c}0.530 \\
(0.400)\end{array}$ & $\begin{array}{c}0.087 \\
(0.415)\end{array}$ \\
\hline Premium h6 & $\begin{array}{l}-0.530 \\
(0.196)^{* *}\end{array}$ & $\begin{array}{c}0.038 \\
(0.558)\end{array}$ & $\begin{array}{l}-0.213 \\
(0.393)\end{array}$ & $\begin{array}{l}-0.120 \\
(0.397)\end{array}$ \\
\hline Premium h7 & $\begin{array}{l}-2.653 \\
(0.289)^{* * *}\end{array}$ & $\begin{array}{l}-0.875 \\
(0.783)\end{array}$ & $\begin{array}{l}-1.332 \\
(0.572)^{*}\end{array}$ & $\begin{array}{l}-0.122 \\
(0.586)\end{array}$ \\
\hline Premium h8 & $\begin{array}{l}-3.122 \\
(0.275)^{* * *}\end{array}$ & $\begin{array}{l}-1.264 \\
(0.647)\end{array}$ & $\begin{array}{l}-2.195 \\
(0.580)^{* * *}\end{array}$ & $\begin{array}{l}-0.318 \\
(0.573)\end{array}$ \\
\hline Premium h9 & $\begin{array}{l}-3.460 \\
(0.266)^{* * *}\end{array}$ & $\begin{array}{l}-2.484 \\
(0.429)^{* * *}\end{array}$ & $\begin{array}{l}-1.327 \\
(0.549)^{*}\end{array}$ & $\begin{array}{l}-1.349 \\
(0.534)^{*}\end{array}$ \\
\hline Premium h10 & $\begin{array}{l}-3.847 \\
(0.293)^{* * *}\end{array}$ & $\begin{array}{l}-2.700 \\
(0.484)^{* * *}\end{array}$ & $\begin{array}{l}-1.416 \\
(0.583)^{*}\end{array}$ & $\begin{array}{l}-2.113 \\
(0.580)^{* * *}\end{array}$ \\
\hline Premium h11 & $\begin{array}{l}-4.612 \\
(0.318)^{* * *}\end{array}$ & $\begin{array}{l}-2.116 \\
(0.632)^{* * *}\end{array}$ & $\begin{array}{l}-1.493 \\
(0.665) *\end{array}$ & $\begin{array}{l}-1.757 \\
(0.593)^{* *}\end{array}$ \\
\hline Premium h12 & $\begin{array}{l}-3.230 \\
(0.224)^{* * *}\end{array}$ & $\begin{array}{l}-1.588 \\
(0.487)^{* *}\end{array}$ & $\begin{array}{l}-1.289 \\
(0.407)^{* *}\end{array}$ & $\begin{array}{l}-1.091 \\
(0.440)^{*}\end{array}$ \\
\hline Premium h13 & $\begin{array}{l}-2.545 \\
(0.207)^{* * *}\end{array}$ & $\begin{array}{l}-1.248 \\
(0.448)^{* *}\end{array}$ & $\begin{array}{l}-1.054 \\
(0.385)^{* *}\end{array}$ & $\begin{array}{l}-0.452 \\
(0.396)\end{array}$ \\
\hline Premium h14 & $\begin{array}{l}-1.952 \\
(0.190)^{* * *}\end{array}$ & $\begin{array}{l}-1.078 \\
(0.347)^{* *}\end{array}$ & $\begin{array}{l}-0.772 \\
(0.362) *\end{array}$ & $\begin{array}{l}-0.184 \\
(0.378)\end{array}$ \\
\hline Premium h15 & $\begin{array}{l}-1.515 \\
(0.205)^{* * *}\end{array}$ & $\begin{array}{l}-0.612 \\
(0.391)\end{array}$ & $\begin{array}{l}-0.257 \\
(0.432)\end{array}$ & $\begin{array}{l}-0.041 \\
(0.374)\end{array}$ \\
\hline Premium h16 & $\begin{array}{l}-1.014 \\
(0.778)\end{array}$ & $\begin{array}{l}-3.094 \\
(1.986)\end{array}$ & $\begin{array}{l}-1.730 \\
(1.644)\end{array}$ & $\begin{array}{c}0.030 \\
(1.033)\end{array}$ \\
\hline Premium h17 & $\begin{array}{l}-2.844 \\
(0.895)^{* *}\end{array}$ & $\begin{array}{l}-3.520 \\
(1.905)\end{array}$ & $\begin{array}{l}-3.244 \\
(1.896)\end{array}$ & $\begin{array}{l}-0.378 \\
(1.336)\end{array}$ \\
\hline
\end{tabular}




\begin{tabular}{lllll}
\hline Premium h18 & -3.791 & -1.905 & -1.600 & -0.535 \\
& $(0.325)^{* * *}$ & $(0.639)^{* *}$ & $(0.592)^{* *}$ & $(0.649)$ \\
Premium h19 & -2.321 & -1.762 & -1.561 & -0.748 \\
& $(0.193)^{* * *}$ & $(0.391)^{* * *}$ & $(0.355)^{* * *}$ & $(0.360)^{*}$ \\
Premium h20 & -1.361 & -1.521 & -1.250 & -0.869 \\
& $(0.140)^{* * *}$ & $(0.263)^{* * *}$ & $(0.242)^{* * *}$ & $(0.277)^{* *}$ \\
Premium h21 & -0.935 & 0.030 & -0.394 & 0.028 \\
& $(0.134)^{* * *}$ & $(0.578)$ & $(0.266)$ & $(0.290)$ \\
Premium h22 & -0.790 & -0.851 & -0.840 & -0.567 \\
& $(0.111)^{* * *}$ & $(0.261)^{* *}$ & $(0.190)^{* * *}$ & $(0.229)^{*}$ \\
Premium h23 & 0.040 & -0.414 & -0.392 & -0.106 \\
& $(0.090)$ & $(0.225)$ & $(0.181)^{*}$ & $(0.186)$ \\
\hline \hline
\end{tabular}

${ }^{*} p<0.05 ;{ }^{* *} p<0.01 ;{ }^{* * *} p<0.001$

Table 5.

Impact of messages informing about failures on premia

This table presents results from regressions which details are provided below.

Column (1) shows coefficient $\alpha_{2}$ from equation:

Premium $_{t}=\beta_{0}+\alpha_{2}$ Failure $_{t}+\beta_{1}$ Var $_{t-1}+\beta_{2}$ Skew $_{t-1}+\beta_{3} X+\varepsilon_{2 t}$ Columns (2), (3) and (4) show coefficients $\alpha_{5}, \alpha_{6}$ and $\alpha_{7}$ from equation: Premium ${ }_{t}=\beta_{0}+\alpha_{5}$ Coal Failure $_{t}+\alpha_{6}$ Nuclear Failure $_{t}+$ $\alpha_{7}$ Hydro Failure $_{t}+\beta_{1}$ Var $_{t-1}+\beta_{2}$ Skew $_{t-1}+\beta_{3} X+\varepsilon_{4 \mathrm{t}}$ In all regressions OLS with Newey-West standard errors procedure is used separately for each hour. Variables Failure, Failure coal, Failure nuclear and Failure hydro are zero-ones variables with 0 when there is no news informing about particular type of failure in the hour and 1 in the opposite case.

\begin{tabular}{lllll}
\hline Premia & Failure(1) & Failure coal(2) & Failure nuclear(3) & Failure hydro(4) \\
\hline Premium h0 & -0.576 & 0.059 & -0.823 & -0.246 \\
& $(0.207)^{* *}$ & $(0.284)$ & $(0.363)^{*}$ & $(0.246)$ \\
Premium h1 & -0.444 & -0.016 & -0.618 & -0.309 \\
& $(0.220)^{*}$ & $(0.269)$ & $(0.410)$ & $(0.248)$ \\
Premium h2 & -0.495 & 0.033 & -0.872 & -0.347 \\
& $(0.249)^{*}$ & $(0.326)$ & $(0.431)^{*}$ & $(0.270)$ \\
Premium h3 & -0.159 & -0.163 & -1.273 & 0.171 \\
& $(0.246)$ & $(0.307)$ & $(0.402)^{* *}$ & $(0.290)$ \\
Premium h4 & -0.271 & -0.229 & -1.501 & 0.014 \\
& $(0.240)$ & $(0.286)$ & $(0.420)^{* * *}$ & $(0.273)$ \\
Premium h5 & 0.324 & 0.036 & -0.621 & 0.247 \\
& $(0.508)$ & $(0.392)$ & $(0.427)$ & $(0.354)$ \\
Premium h6 & -0.204 & -0.659 & -0.003 & -0.161 \\
& $(0.429)$ & $(0.382)$ & $(0.509)$ & $(0.337)$ \\
Premium h7 & -0.582 & -1.504 & 0.962 & 0.061 \\
& $(0.653)$ & $(0.590)^{*}$ & $(0.634)$ & $(0.534)$ \\
\hline
\end{tabular}




\begin{tabular}{|c|c|c|c|c|}
\hline Premium h8 & $\begin{array}{l}-1.115 \\
(0.608)\end{array}$ & $\begin{array}{l}-1.946 \\
(0.607)^{* *}\end{array}$ & $\begin{array}{l}-0.840 \\
(0.821)\end{array}$ & $\begin{array}{l}-0.503 \\
(0.550)\end{array}$ \\
\hline Premium h9 & $\begin{array}{l}-2.256 \\
(0.462)^{* * *}\end{array}$ & $\begin{array}{l}-1.370 \\
(0.626)^{*}\end{array}$ & $\begin{array}{l}-0.252 \\
(0.794)\end{array}$ & $\begin{array}{l}-1.539 \\
(0.626)^{*}\end{array}$ \\
\hline Premium h10 & $\begin{array}{l}-1.938 \\
(0.512)^{* * *}\end{array}$ & $\begin{array}{l}-1.232 \\
(0.657)\end{array}$ & $\begin{array}{l}-0.941 \\
(0.854)\end{array}$ & $\begin{array}{l}-2.175 \\
(0.615)^{* * *}\end{array}$ \\
\hline Premium h11 & $\begin{array}{l}-1.467 \\
(0.589) *\end{array}$ & $\begin{array}{l}-1.351 \\
(0.713)\end{array}$ & $\begin{array}{c}0.043 \\
(0.880)\end{array}$ & $\begin{array}{l}-1.442 \\
(0.652)^{*}\end{array}$ \\
\hline Premium h12 & $\begin{array}{l}-1.203 \\
(0.450)^{* *}\end{array}$ & $\begin{array}{l}-1.362 \\
(0.473)^{* *}\end{array}$ & $\begin{array}{c}0.040 \\
(0.534)\end{array}$ & $\begin{array}{l}-1.357 \\
(0.445)^{* *}\end{array}$ \\
\hline Premium h13 & $\begin{array}{l}-1.030 \\
(0.433)^{*}\end{array}$ & $\begin{array}{c}-1.697 \\
(0.435)^{* * *}\end{array}$ & $\begin{array}{l}-0.140 \\
(0.513)\end{array}$ & $\begin{array}{l}-0.493 \\
(0.407)\end{array}$ \\
\hline Premium h14 & $\begin{array}{l}-0.548 \\
(0.430)\end{array}$ & $\begin{array}{l}-0.713 \\
(0.381)\end{array}$ & $\begin{array}{l}-0.764 \\
(0.459)\end{array}$ & $\begin{array}{l}-0.143 \\
(0.373)\end{array}$ \\
\hline Premium h15 & $\begin{array}{l}-0.926 \\
(0.308)^{* *}\end{array}$ & $\begin{array}{l}-0.477 \\
(0.420)\end{array}$ & $\begin{array}{l}-1.027 \\
(0.510)^{*}\end{array}$ & $\begin{array}{c}0.271 \\
(0.412)\end{array}$ \\
\hline Premium h16 & $\begin{array}{l}-1.844 \\
(1.142)\end{array}$ & $\begin{array}{l}-1.129 \\
(1.218)\end{array}$ & $\begin{array}{l}-1.460 \\
(1.149)\end{array}$ & $\begin{array}{c}1.372 \\
(1.197)\end{array}$ \\
\hline Premium h17 & $\begin{array}{l}-2.487 \\
(1.293)\end{array}$ & $\begin{array}{l}-2.907 \\
(1.608)\end{array}$ & $\begin{array}{l}-0.230 \\
(1.518)\end{array}$ & $\begin{array}{l}-0.368 \\
(1.398)\end{array}$ \\
\hline Premium h18 & $\begin{array}{l}-1.746 \\
(0.540)^{* *}\end{array}$ & $\begin{array}{l}-1.146 \\
(0.711)\end{array}$ & $\begin{array}{c}0.344 \\
(0.647)\end{array}$ & $\begin{array}{l}-1.153 \\
(0.604)\end{array}$ \\
\hline Premium h19 & $\begin{array}{l}-1.187 \\
(0.388)^{* *}\end{array}$ & $\begin{array}{l}-1.120 \\
(0.390)^{* *}\end{array}$ & $\begin{array}{c}0.155 \\
(0.450)\end{array}$ & $\begin{array}{l}-0.508 \\
(0.372)\end{array}$ \\
\hline Premium h20 & $\begin{array}{l}-1.024 \\
(0.271)^{* * *}\end{array}$ & $\begin{array}{c}-1.446 \\
(0.275)^{* * *}\end{array}$ & $\begin{array}{l}-0.222 \\
(0.312)\end{array}$ & $\begin{array}{l}-0.561 \\
(0.280)^{*}\end{array}$ \\
\hline Premium h21 & $\begin{array}{c}0.071 \\
(0.390)\end{array}$ & $\begin{array}{l}-0.494 \\
(0.256)\end{array}$ & $\begin{array}{l}-0.157 \\
(0.292)\end{array}$ & $\begin{array}{l}-0.188 \\
(0.264)\end{array}$ \\
\hline Premium h22 & $\begin{array}{l}-0.430 \\
(0.310)\end{array}$ & $\begin{array}{c}-0.934 \\
(0.215)^{* * *}\end{array}$ & $\begin{array}{l}-0.610 \\
(0.265)^{*}\end{array}$ & $\begin{array}{l}-0.407 \\
(0.216)\end{array}$ \\
\hline Premium h23 & $\begin{array}{l}-0.364 \\
(0.197)\end{array}$ & $\begin{array}{l}-0.400 \\
(0.181)^{*}\end{array}$ & $\begin{array}{l}-0.501 \\
(0.237)^{*}\end{array}$ & $\begin{array}{c}-0.017 \\
(0.182)\end{array}$ \\
\hline
\end{tabular}

${ }^{*} p<0.05 ;{ }^{* *} p<0.01 ;{ }^{* * *} p<0.001$ 